\title{
PERFORMANCE EVALUATION OF A MULTI STOREY CAR PARKING STRUCTURE UNDER STRENGTH IRREGULARITIES BY PUSH OVER
}

\author{
ANALYSIS \\ Vasanth Acharya ${ }^{1}$, Akshaya ${ }^{2}$, Shivananda S.M ${ }^{3}$, H L Suresh ${ }^{4}$ \\ ${ }^{1}$ Post Graduate student, Structural Engineering, Manipal Institute of Technology Manipal, Karnataka, India \\ ${ }^{2}$ Assistant Professor, Civil Engineering department, Manipal Institute of Technology, Karnataka, India. \\ ${ }^{3}$ Structural Engineer (Underground Structures), GEODATA India Pvt ltd, Bangalore, Karnataka, India \\ ${ }^{4}$ Managing Director, Structural Engineer, Civil Tech India Pvt ltd, Bangalore, Karnataka, India
}

\begin{abstract}
Buildings, which appeared to be strong enough, may crumble like houses of cards during earthquake and deficiencies may be exposed. In last decade, four devastating earthquakes of world have been occurred in India, and low to mild intensities earthquakes are shaking our land frequently. It has raised the questions about the adequacy of framed structures to resist strong motions, since many buildings suffered great damage or collapsed. A number of multi-storey car parking structures in urban India are constructed at airports, railway stations, etc. in regular and irregular shape for architectural, aesthetic or economic reasons to reduce the problem of parking. The materials being used for the structures may be having same properties and in some times it may vary in strength, mass etc. To evaluate the performance of framed buildings under future expected earthquakes, a non-linear static pushover analysis has been conducted on a typical multi-storey car parking structure. To achieve this objective, a 3D framed multi storey car parking structure $(G+3)$ is modeled in SAP 2000 in which the structure is open in all stories with rigid floors. Such features are highly undesirable in buildings built in seismically active areas because of lesser mass of the structures, this has been verified in numerous experiences of strong shaking during the past earthquakes. We are investigating the effect of strength irregularities in the present multi-storey car parking structure of $R / C$ frames on the seismic performance using nonlinear static push-over analysis based on computational models. From output non-linear analysis, we compare the Base shear and Displacement occurs in different strength irregularities for the different load combinations in seismic zone IV.
\end{abstract}

Keywords: Strength irregularities, Earthquake, SAP2000, Performance point, Capacity curve. ****

\section{INTRODUCTION}

The recent earthquakes including the last Algerian earthquake in which many concrete structures have been severely damaged or collapsed, have indicated the need for evaluating the seismic adequacy of existing buildings. In particular, the rehabilitation of older concrete structures in high seismicity areas is matter of growing concern, since structures venerable to damage must be identified and an acceptable level of safety must be determined. To make such assessment, simplified linear-elastic methods are not adequate. Thus, the structural engineering community has developed a new generation of design and seismic procedures that incorporate performance based structure and are moving away from Simplified linear elastic methods and towards a more non-linear technique. Recent interests in the development of performance based codes for the design or rehabilitation of buildings in seismic active areas show that an inelastic procedure commonly referred to as the pushover analysis is a viable method to assess damage vulnerability of buildings.
Basically, a pushover analysis is a series of incremental static analysis carried out to develop a capacity curve for the building. Based on the capacity curve, a target displacement which is an estimate of the displacement that the design earthquake will produce on the building is determined. The extent of damage experienced by the structure at this target displacement is considered representative of the damage experienced by the building when subjected to design level ground shaking. Many methods were presented to apply the nonlinear static pushover (NSP) to structures [2]. Nonlinear static analysis, or pushover analysis, has been developed over the past twenty years and has become the preferred analysis procedure for design and seismic performance evaluation purposes as the procedure is relatively simple and considers post elastic behavior. However, the procedure involves certain approximations and simplifications that some amount of variation is always expected to exist in seismic demand prediction of pushover analysis [1].

Although, in literature, pushover analysis has been shown to capture essential structural response characteristics under 
seismic action, the accuracy and the reliability of pushover analysis in predicting global and local seismic demands for all structures have been a subject of discussion and improved pushover procedures have been proposed to overcome the certain limitations of traditional pushover procedures. However, the improved procedures are mostly computationally demanding and conceptually complex that uses of such procedures are impractical in engineering profession and codes[3].

\section{METHODOLOGY}

To observe the performance of the strength irregular building, we have modeled a multi-storey car parking structure $(\mathrm{G}+3)$ with open storeys at all the floors is taken and analyzed in SAP2000. All columns in the models are to be fixed at the base. The Height of the each floor is $3.2 \mathrm{~m}$. Slab has been modeled as rigid diaphragm element of $150 \mathrm{~mm}$ thick throughout in the present study.

Live load on floor is taken as $2.5 \mathrm{kN} / \mathrm{m}^{2}$ and on roof is $1.5 \mathrm{kN} / \mathrm{m}^{2}$. Floor finish on the floor is $1 \mathrm{kN} / \mathrm{m}^{2}$. Weathering course on roof is $1 \mathrm{kN} / \mathrm{m}^{2}$. The seismic weight is calculated conforming to IS 1893-2002(part-I). The unit weights of concrete is taken as $24 \mathrm{kN} / \mathrm{m}^{3}$ The grade of concrete for column is M-25 and for beam and slab is M-20.The building has been modeled as ordinary and special moment resisting frame to differentiate the ductile and non-ductile performance of the structure when strength irregularity occurs in the structure, considered to be situated in seismic zone IV having medium soil and intended for car parking use.

Building $(\mathrm{G}+3)$ is circular in structure, having peripheral circular columns of $0.75 \mathrm{~m}$ dia, whereas all inner circular columns are of dia $0.45 \mathrm{~m}$. The columns which are located in between periphery and inner side are of dia $0.6 \mathrm{~m}$. While the beam sizes are given as 200x450, 200x600, 200x750 and $300 \times 750$ in different parts of the structure by considering the necessity. Also a circular ramp has been provided at the center for the proper movements of the vehicles as per the codal provisions.

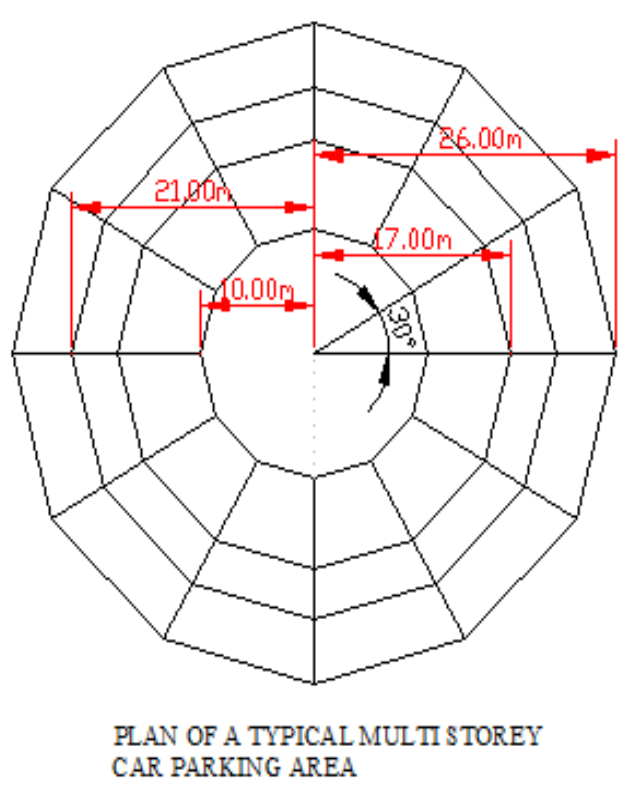

Fig-1: plan of typical multi-storey car parking structure.

\section{MODELING \& ANALYSIS OF BUILDING}

After designing and detailing the reinforced concrete frame structures, a nonlinear pushover analysis is carried out for evaluating the structural seismic response. The pushover analysis consists of the application of gravity loads and a representative lateral load pattern. After assigning all properties of the models, the displacement -controlled pushover analysis of the models are carried out. The models are pushed in monotonically increasing order until target displacement is reached or structure loses equilibrium; whichever occurs first. For this purpose, target displacement at roof level and number of steps in which this displacement must be defined. In this study, target displacement is taken $4 \%$ of building height. Pushover curve is a base shear force versus roof displacement curve. The peak of this curve represents maximum lateral load carrying capacity of the structure. The initial stiffness of the structure is obtained from the tangent at pushover curve at zero load level. The collapse is assumed when structure losses its $75 \%$ strength and corresponding roof displacement is called "maximum roof displacement".

The general finite element package SAP 2000 has been used for the analyses. A three-dimensional model of each structure has been created to undertake the non-linear analysis. Beams and columns are modeled as nonlinear frame elements with lumped plasticity at the start and the end of each element. SAP 2000 provides default-hinge Properties and recommends PMM hinges for columns and M3 hinges for beams as described in FEMA-356[3] 


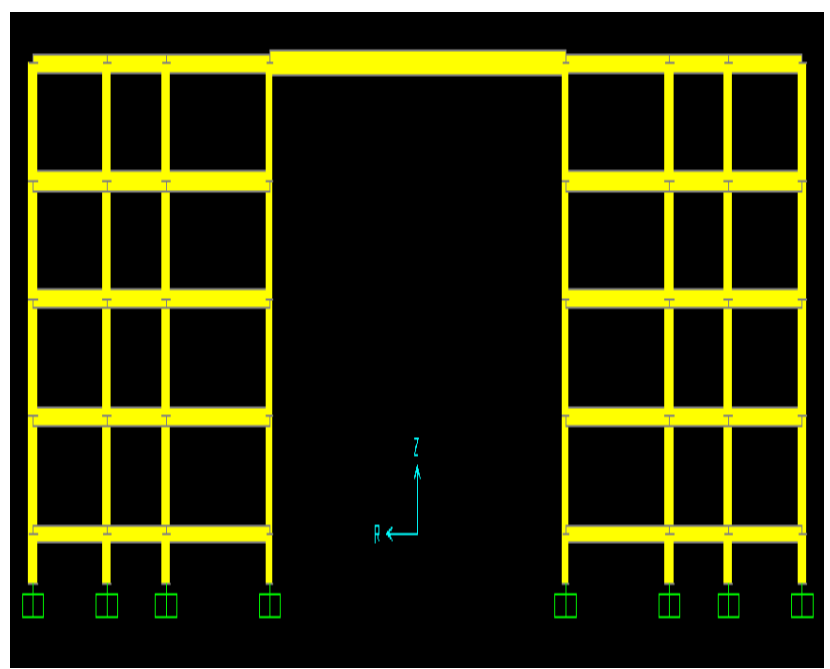

Fig.2: Sectional Elevation of the car parking structure.

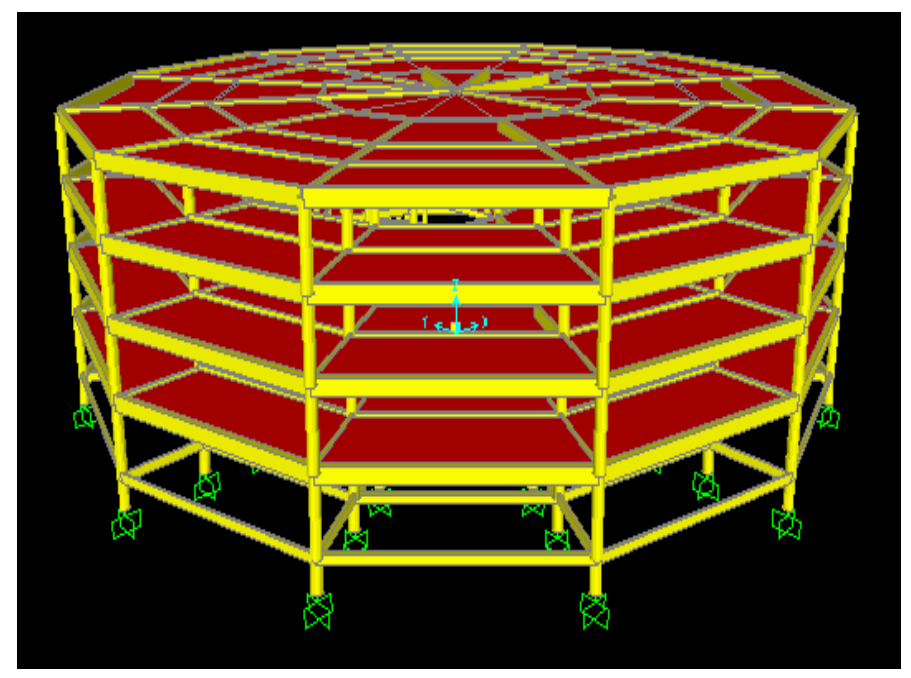

Fig.3 Dimensional model of the structure.

\subsection{Case1: Non Ductile Detailing Push over Analysis}

Case1 study is for non-ductile detailing structure. The members were design as OMRF as according to IS: 456. Ductile detailing is not considered in this frame. Pushover analysis is performed on this frame using displacement pushover approach. The grade of concrete and steel has been varied to observe the performance of the structure when strength irregularity occurs.

\subsection{Case2: Ductile Detailing Push over Analysis}

Members were designed as SMRF according to IS: 13920. Pushover analysis has been performed in ductile case and the results are shown below. The grade of concrete and steel has been varied to observe the performance of the structure.

\section{RESULTS AND DISCUSSION}

In the present study, non-linear response of multi-storey car parking structure using SAP2000 under the loading has been carried out. The objective of this study is to see the variation of load- displacement graph and check the maximum base shear and displacement of the frame for the ordinary and special moment resistance structure in the case of strength irregularity. For the columns the concrete grade and steel grade has been varied in this study. After running the analysis, the pushover curve is obtained as shown in figures.

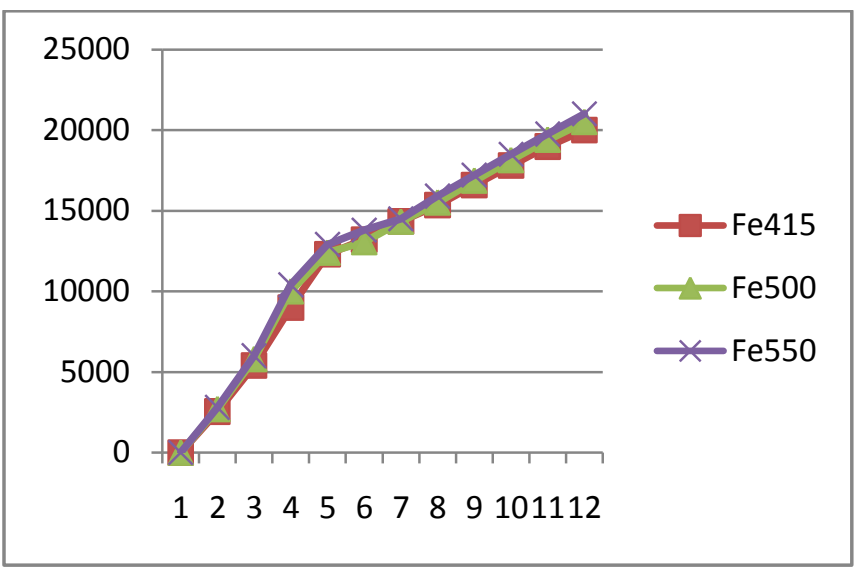

Graph1: Load vs Displacement graph (Comparision using different strength of steel - M25 grade of concrete in coumns OMRF)

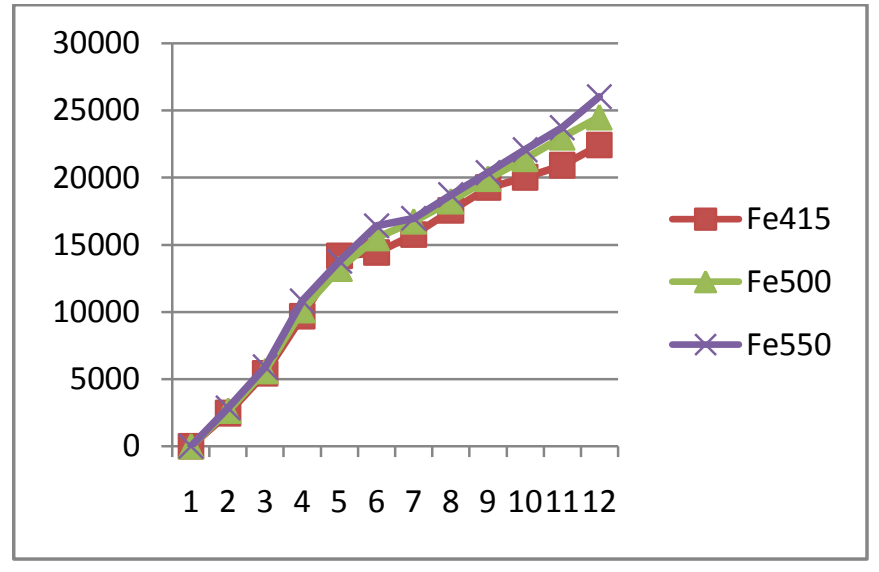

Graph2: Load vs Displacement graph (Comparision using different strength of steel - M30 grade of concrete in coumns OMRF) 


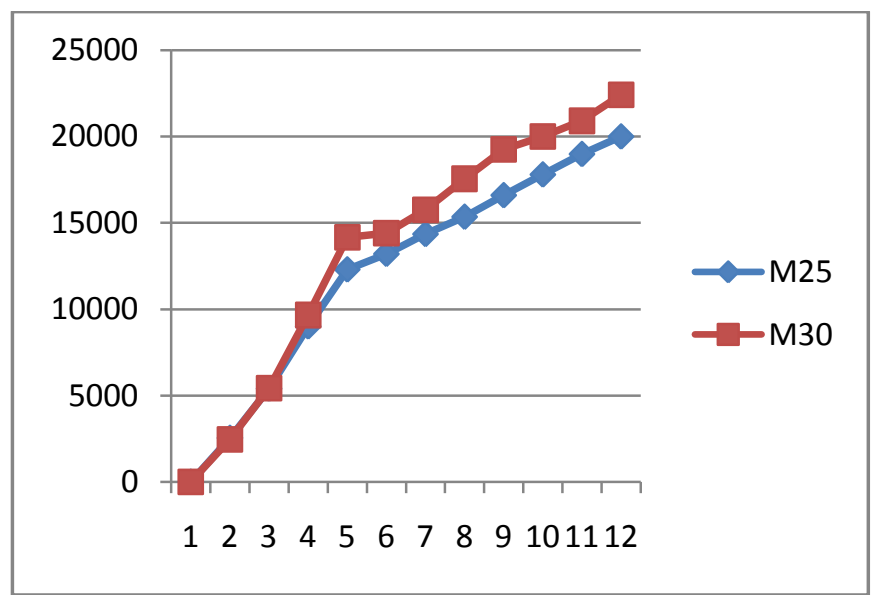

Graph3: Load vs Displacement graph (Comparision using different grade of concrete $-\mathrm{Fe} 415$ grade of steel - OMRF)

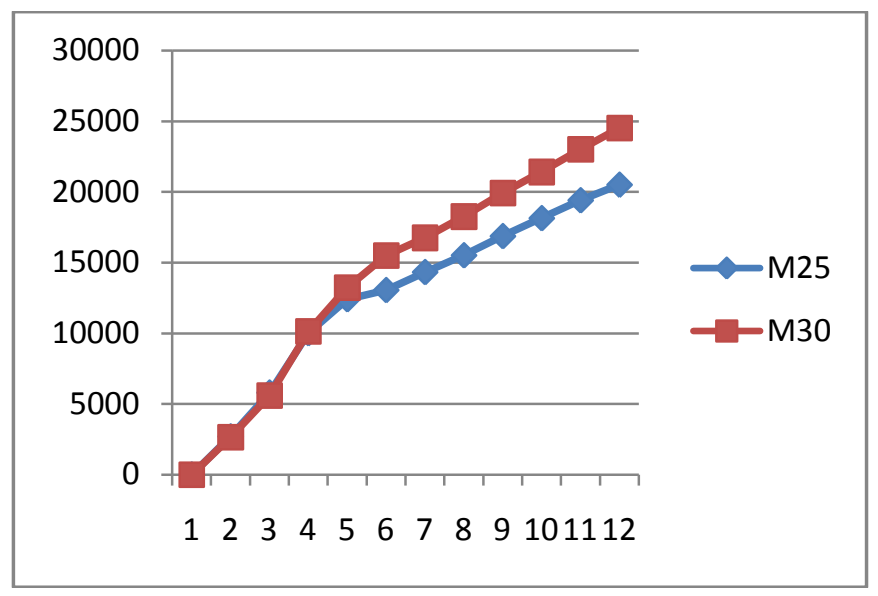

Graph4: Load vs Displacement graph (Comparision using different grade of concrete - Fe415 grade of steel - OMRF)

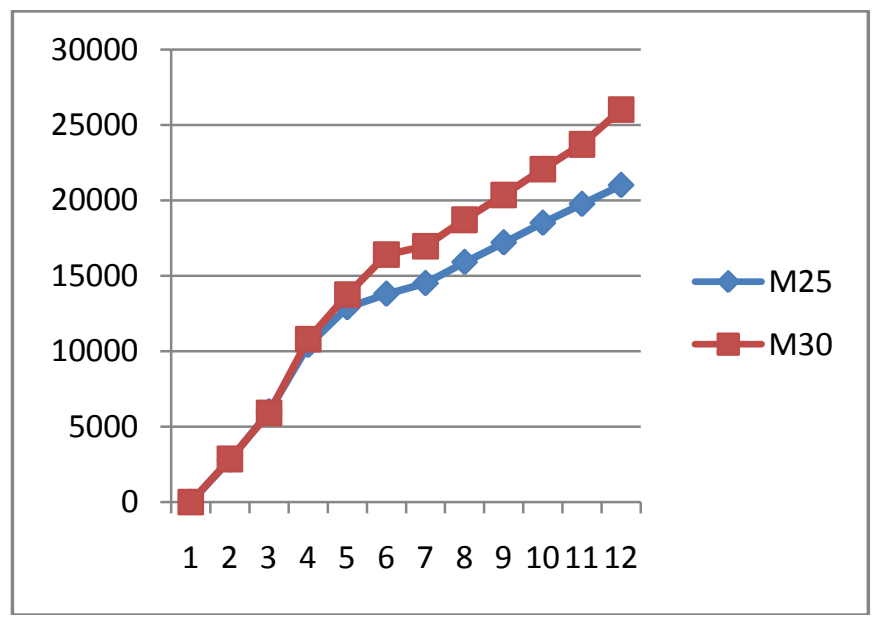

Graph5: Load vs Displacement graph (Comparision using different grade of concrete - Fe500 grade of steel - OMRF)

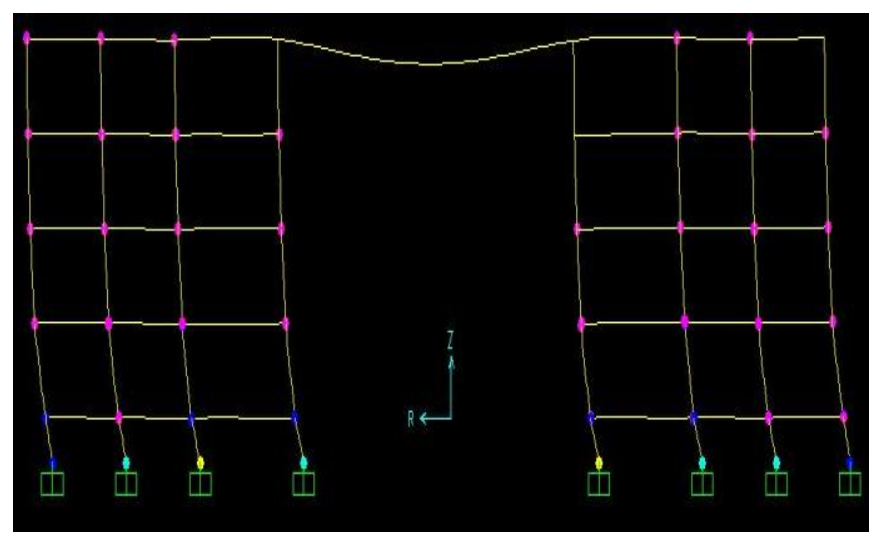

Fig4: Mechanism of hinge formation.

1. From the graph1 and graph2, it can be observed that, by using the M30 grade of concrete in place of M25 grade, the Base shear can be increased by around $15 \%$ for $\mathrm{Fe} 415$ grade steel, around $20 \%$ for $\mathrm{Fe} 500$ grade steel and $25 \%$ for Fe550 grade steel. The horizontal displacement is also reduced up to $10 \%$.

2. From graph1, it can be observed that, by changing the grade of steel in M25 grade of concrete in column, the improvement in Base shear is in very lesser percentage, so that we can say it as negligible. But the same can be noted in M30 grade of concrete combination, the improvement in Base shear capacity is around $15 \%$.

3. From graph3, graph4 \& graph5, it can be observed that using higher grades of concrete with the different grades of steel, we can achieve the considerable improvement in the Base shear \& the decrement in horizontal displacement.

4. By the Capacity Spectrum curves, it is also observed that the by varying the strength parameters in the structure the performance point can be improved up to some considerable percentage.

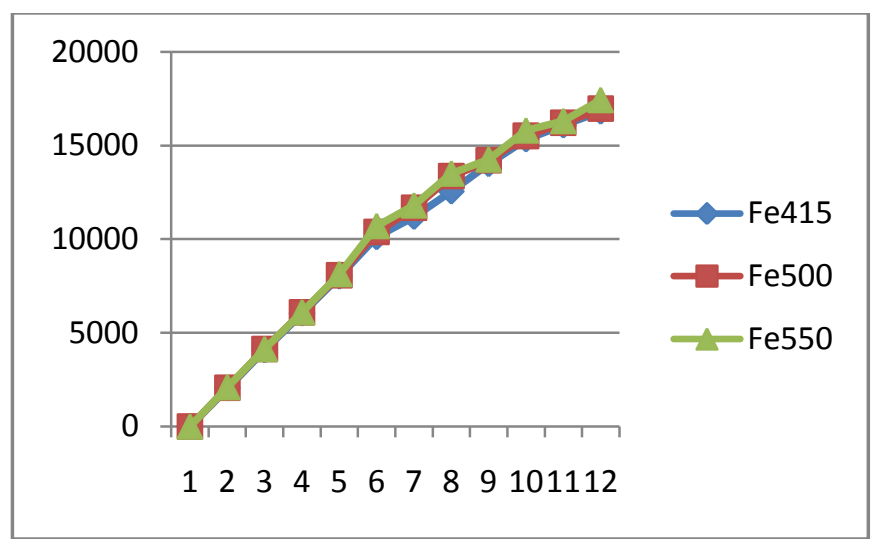

Graph6: Load vs Displacement graph (Comparision using different strength of steel - M25 grade of concrete in coumns SMRF) 


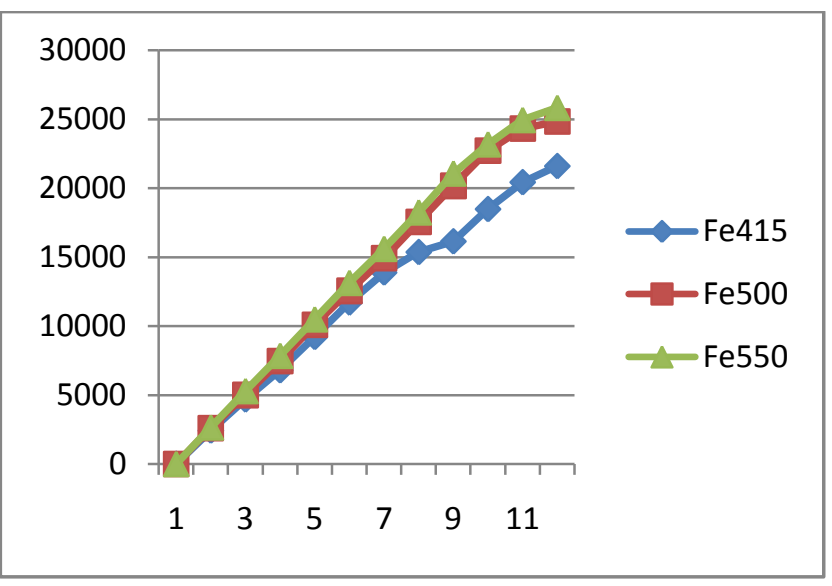

Graph7: Load vs Displacement graph (Comparision using different strength of steel - M30 grade of concrete in coumns SMRF)

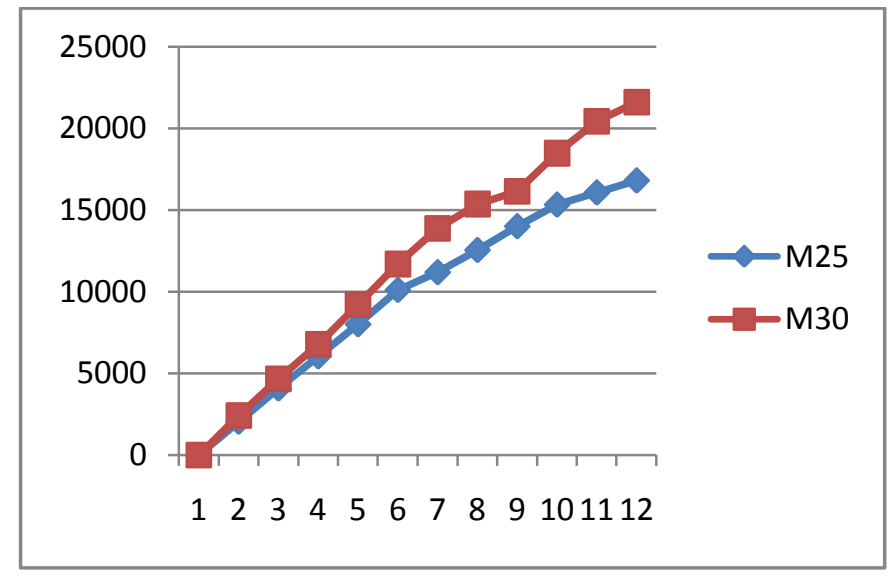

Graph8: Load vs Displacement graph (Comparision using different grade of concrete - Fe415 grade of steel - SMRF)

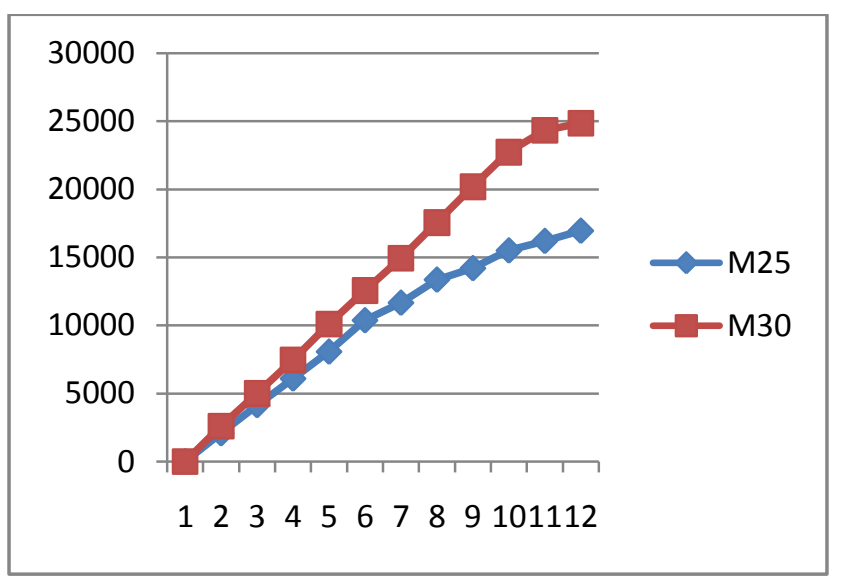

Graph9: Load vs Displacement graph (Comparision using different grade of concrete - Fe500 grade of steel - SMRF)

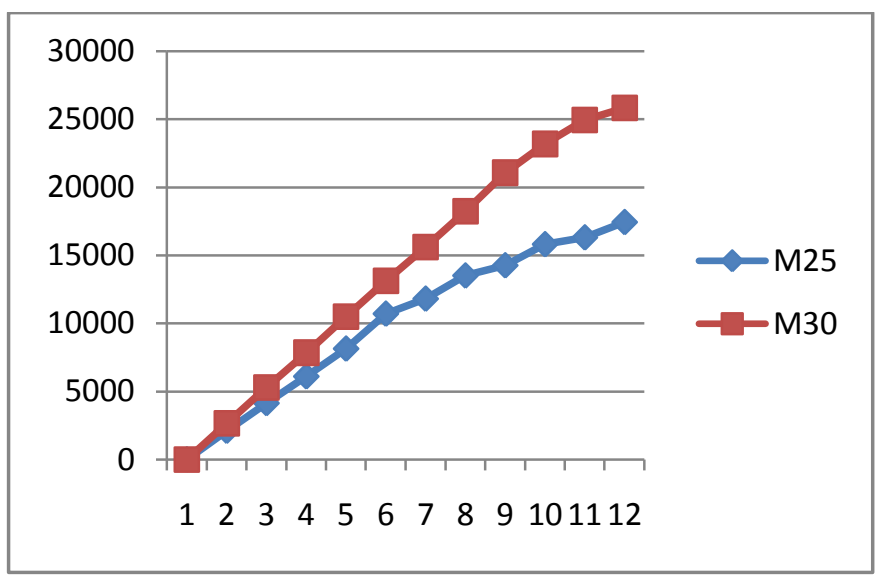

Graph10: Load vs Displacement graph (Comparision using different grade of concrete -Fe550 grade of steel - SMRF)

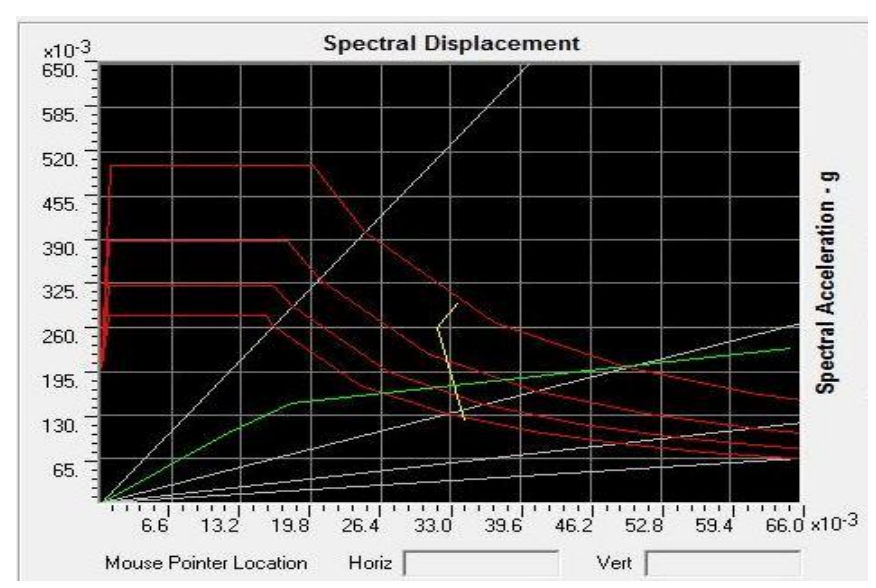

Fig5: Demand crve / Capacity curve

1. All the points of discussion remains same in the ductile design(SMRF) as it is observed in non ductile design(OMRF). The increment in the base shear and the variation in the lateral drifts are in the similar passion.

2. The important observation in the ductile design(SMRF) is, the increment in Base shear and Performance point, for the given strength of materials is higher, as the percentage of steel is increased.

\section{CONCLUSIONS}

- At the time of design, the designer should have cooncerned about the self weight of the structure, which is comparatively very lesser in the car parking structures, as there will be no(or very lesser inn number) infill walls will be present. Hence, the lateral displacement will occur more.

- As the percentage improvement in resisting the lateral drift, by changing or using higher grades of concrete and steel, it is recommonded to go for lateral 
ties, shear walls etc. as they will give more better result.

- It is recommonded to use the ductile detailing(SMRF) for the special structures like this, which will be having lesser self weight and having lesser Base shear, to avoid the lateral drift.

- It is better to optimise the grade of concrete and grade of steel while analysing and designing the structure to avoid the lateral drift upto some extent and also to improve the performance of the structure.

- In future work, the variation in the height of the structure can be taken as one major input data for the analysis, to optimise the better results.

\section{REFERENCES}

[1] Ms. Nivedita N. Raut \& Ms. Swati D. Ambadkar. Pushover Analysis of Multistoried Building. Global Journal of Researches in Engineering Civil And Structural Engineering. Volume 13 Issue 4 Version 1.0 Year (2013)

[2] P. Poluraju, P. V. S. Nageswara Rao. Pushover analysis of reinforced concrete frame structure using SAP 2000. International Journal of Earth Sciences and Engineering. ISSN 0974-5904, Volume 04, No 06 SPL, October 2011, pp. 684-690

[3] A. Kadid* and A. Boumrkik. Pushover analysis of reinforced concrete frame Structure, Technicalnote, asian journal of civil engineering (building and housing) vol. 9, no. 1 (2008) Pages 75-83

[4] IS 456:2000 "Indian Standard Plain and Reinforced Concrete Code of Practice".

[5] FEMA273 [1997] "NEHRP Guidelines for the seismic rehabilitation of buildings, Report No.FEMA273," Federal Emergency Management Agency, October.

[6] IS 1893 (Part 1):2002 Indian Standard "Criteria for Earthquake Resistant Design of Structures" Part 1 General Provision and Buildings, (Fifth Revision).

[7] IS 13920 (1993): Indian standard "Ductile detailing of reinforced concrete structures subjected to seismic forces - Code of practice".

[8] ATC 40 [1996] "Seismic evaluation and retrofit of concrete buildings, Vol No.1 and "Applied Technology

Council, Seismic Safety Commission, State of California.

* SAP 2000 Nonlinear Version 14.2.4 Software Package.

* SAP 2000 Nonlinear Manuals.

* SAP 2000 Videos. 